\title{
Pathways to balance mitochondrial translation and protein import
}

\author{
Chantal Priesnitz ${ }^{1,2}$ and Thomas Becker ${ }^{1,3}$ \\ ${ }^{1}$ Institute of Biochemistry and Molecular Biology, Center for Biochemistry and Molecular Cell Research (ZBMZ), Faculty of \\ Medicine, University of Freiburg, D-79104 Freiburg, Germany; ${ }^{2}$ Faculty of Biology, University of Freiburg, D-79104 Freiburg, \\ Germany; ${ }^{3}$ BIOSS Centre for Biological Signaling Studies, University of Freiburg, D-79104 Freiburg, Germany
}

\begin{abstract}
Mitochondria contain their own genome that encodes for a small number of proteins, while the vast majority of mitochondrial proteins is produced on cytosolic ribosomes. The formation of respiratory chain complexes depends on the coordinated biogenesis of mitochondrially encoded and nuclear-encoded subunits. In this review, we describe pathways that adjust mitochondrial protein synthesis and import of nuclear-encoded subunits to the assembly of respiratory chain complexes. Furthermore, we outline how defects in protein import into mitochondria affect nuclear gene expression to maintain protein homeostasis under physiological and stress conditions.
\end{abstract}

Mitochondria originated from the incorporation of a prokaryote similar to existing a-proteobacteria by a eukaryotic ancestor cell >1.5 billion years ago (Zimorski et al. 2014; Archibald 2015). During the course of evolution, the vast majority of genetic information of the endosymbiont was transferred to the host nuclear genome. Mitochondria contain $\sim 1000$ proteins in baker's yeast Saccharomyces cerevisiae and 1500 proteins in humans (Sickmann et al. 2003; Pagliarini et al. 2008; Morgenstern et al. 2017). About $99 \%$ of the mitochondrial proteins are synthesized as precursors on cytosolic ribosomes and imported into the target organelle by dedicated protein translocases. Mitochondria retain their own genome that encodes eight proteins in yeast (Table 1) and 13 proteins in humans (Hällberg and Larsson 2014; Ott et al. 2016). Remarkably, about one quarter of the mitochondrial proteins in yeast ( 250 proteins) are involved in expression and maintenance of the mitochondrial genome, reflecting the central role of the gene products for mitochondrial function (Sickmann et al. 2003; Morgenstern et al. 2017).

Mitochondria fulfill many functions for cellular metabolism. Biosynthesis of lipids and amino acids, degradation of fatty acids, formation of iron-sulfur clusters, and reaction steps of heme biosynthesis and the urea cycle occur

[Keywords: mitochondria; respiratory chain; protein sorting; mitochondrial gene expression]

Corresponding author: thomas.becker@biochemie.uni-freiburg.de

Article is online at http://www.genesdev.org/cgi/doi/10.1101/gad.316547. 118 . within mitochondria. The most prominent function of mitochondria is the production of the bulk of cellular ATP by oxidative phosphorylation. In this process, respiratory chain complexes of the inner membrane transport electrons from the reducing equivalents $\mathrm{NADH}$ and $\mathrm{FADH}_{2}$ to oxygen to produce water. The respiratory chain complexes use the released energy from the electron transport process to establish a proton gradient across the inner membrane. The proton gradient drives the activity of the $\mathrm{F}_{1} \mathrm{~F}_{\mathrm{o}}$-ATP synthase (ATP synthase) to generate ATP from ADP and phosphate by a complex molecular mechanism. In humans, the respiratory chain is composed of four multisubunit protein complexes: the NADH dehydrogenase (complex I), succinate dehydrogenase (complex II), cytochrome $b c_{1}$ complex (complex III), and cytochrome $c$ oxidase (complex IV). Mitochondria of baker's yeast S. cerevisiae lack a canonical complex I but contain three alternative NADH dehydrogenases in the inner membrane that do not pump protons across the inner membrane: The internal NADH dehydrogenase (Ndi1) oxidizes NADH produced inside mitochondria, whereas two external NADH dehydrogenases (Nde1 and Nde2) oxidize cytosolic NADH (Marres et al. 1991; Luttik et al. 1998; Small and McAlister-Henn 1998). A typical feature of the mitochondrial respiratory chain is the organization of the cytochrome $b c 1$ complex, cytochrome $c$ oxidase, and mammalian $\mathrm{NADH}$ dehydrogenase in respiratory chain supercomplexes (Cruciat et al. 2000; Schägger and Pfeiffer 2000; Böttinger et al. 2012; Gu et al. 2016; Letts et al. 2016).

Respiratory chain complexes I, III, and IV as well as the ATP synthase contain proteins of dual genetic origin. Mitochondrially encoded proteins constitute reactive centers and associate with many nuclear-encoded proteins in functional protein machineries. The assembly of these protein complexes is a complicated process involving a large number of assembly factors as well as the coordinated expression of nuclear and mitochondrial genes

(C) 2018 Priesnitz and Becker This article is distributed exclusively by Cold Spring Harbor Laboratory Press for the first six months after the full-issue publication date (see http://genesdev.cshlp.org/site/misc/ terms.xhtml). After six months, it is available under a Creative Commons License (Attribution-NonCommercial 4.0 International), as described at http://creativecommons.org/licenses/by-nc/4.0/. 
Table 1. Translational regulators in yeast mitochondria

\begin{tabular}{|c|c|c|}
\hline Mitochondrial gene & Translational regulator & Reported function \\
\hline \multicolumn{3}{|c|}{ Cytochrome $b c_{1}$ complex } \\
\hline \multirow[t]{9}{*}{$C O B$} & Cbs1 & Acts on the $5^{\prime}$ untranslated region (UTR) of $C O B$ mRNA \\
\hline & & Associates with mitoribosomes \\
\hline & Cbs2 & Acts on the $5^{\prime}$ UTR of $C O B$ mRNA \\
\hline & & Associates with mitoribosomes \\
\hline & Cbp1 & Acts on the $5^{\prime}$ UTR of $C O B$ mRNA \\
\hline & & Stabilizes $C O B$ mRNA \\
\hline & Cbp3 & Forms a complex with Cpb6 \\
\hline & Cbp6 & Associates with mitoribosomes \\
\hline & & Couples translation of $C O B$ mRNA with assembly of the cytochrome $b c_{1}$ complex \\
\hline \multicolumn{3}{|r|}{ 然 } \\
\hline \multirow[t]{6}{*}{ COX1 } & Mss51 & Acts on the $5^{\prime}$ UTR of $C O X 1$ mRNA \\
\hline & & Couples translation of $C O X 1 \mathrm{mRNA}$ with assembly of cytochrome $c$ oxidase \\
\hline & Pet309 & Binds to COX1 mRNA \\
\hline & & Stabilizes COX1 mRNA \\
\hline & Mam33 & Translational activator during fermentative growth \\
\hline & & Unknown molecular function \\
\hline COX2 & Pet111 & Acts on the $5^{\prime}$ UTR of $C O X 2$ mRNA \\
\hline \multirow[t]{3}{*}{ COX3 } & Pet54 & Pet54/Pet122/Pet494 form a complex \\
\hline & Pet122 & Acts on the $5^{\prime}$ UTR of $C O X 3$ mRNA \\
\hline & Pet494 & \\
\hline \multicolumn{3}{|l|}{ ATP synthase } \\
\hline ATP6 & Atp22 & Unknown function \\
\hline \multirow[t]{2}{*}{ ATP6/ATP8 } & Smt1 & Translational repressor \\
\hline & & Binds ATP $6 / A T P 8$ mRNA \\
\hline \multirow[t]{4}{*}{ ATP9 } & Aep1 & Unknown function \\
\hline & Aep2 & Acts on $5^{\prime}$ UTR of $A T P 9$ mRNA \\
\hline & Atp25 & Stabilization of $A T P 9$ mRNA \\
\hline & & Promotes assembly of Atp9 ring \\
\hline \multicolumn{3}{|l|}{ Mitoribosome } \\
\hline VAR1 & Sov1 & Unknown function \\
\hline
\end{tabular}

Protein-encoding mitochondrial genes and their translational regulators in S. cerevisiae are listed. Smt1 acts as translational repressor, while all other translation regulators activate the expression of their target genes.

(Fox 2012; Smith et al. 2012; Dennerlein et al. 2017; Song et al. 2018; Timón-Gómez et al. 2018). Malfunctions in this process cause an accumulation of unassembled subunits or vestigial complexes, which in turn leads to increased levels of reactive oxygen species that are harmful to the cell (Khalimonchuk et al. 2007; Zara et al. 2007; He et al. 2018). Defects in the formation of respiratory chain complexes have been linked to several diseases such as neurodegenerative disorders and cardiomyopathies (Shoubridge 2001; Smeitink et al. 2006). A recent study revealed that cytosolic protein synthesis and mitochondrial protein synthesis are synchronized in yeast cells (Couvillion et al. 2016). How the expression of the two different genomes is coordinated is poorly understood. In this review, we highlight recent findings that shed light into this fundamental biological question. We describe molecular circuits that adjust mitochondrial protein production to the assembly stage of respiratory chain complexes and summarize the novel concept that the rate of mitochondrial translation can be adjusted to the import of nuclear-encoded proteins. Finally, we outline the critical role of protein import pathways in the regulation of mitochondrial protein homeostasis during cellular signaling processes.

\section{Expression of the mitochondrial genome}

Depending on the organism and cell type, eukaryotic cells may contain up to many thousands of copies of mitochondrial DNA (mtDNA). Due to the presence of noncoding sequences, the size of the mitochondrial genome is extremely variable between species. Human and yeast mitochondrial genomes contain 16.5 and $75 \mathrm{~kb}$, respectively (Hällberg and Larsson 2014; Ott et al. 2016). The two strands of mtDNA can be separated by density centrifugation and are therefore termed heavy and light strands (Battey and Clayton 1978). The circular mtDNA is densely packed into nucleoids with proteins such as human transcription factor A (TFAM). Replication, repair, and transcription of mtDNA take place within the nucleoid structure (Hällberg and Larsson 2014; Pearce et al. 2017). Transcription of the light and heavy strands of mtDNA by the mitochondrial RNA polymerase results in the formation of two polycistronic transcripts. In human mitochondria, maturation of the primary transcripts occurs in RNA granules. Here, the RNA transcripts are processed by RNase $\mathrm{P}$ at the $5^{\prime}$ end and by ELAC protein 2 at the $3^{\prime}$ end to form monocistronic and bicistronic transcripts that are further modified by polyadenylation and 
nucleotide modification (Hällberg and Larsson 2014; Pearce et al. 2017).

Distinct mechanisms control transcription of the mitochondrial genes. Several specific transcriptional factors localize to mitochondria to regulate expression of the mitochondrial genome (Quirós et al. 2016; Pearce et al. 2017). Recently, subunits of the nonspecific lethal (NSL) complex, including the acetyl transferase MOF (males absent on the first), were found in mitochondria of human cell lines (Chatterjee et al. 2016). The NSL complex binds to the promoter region of thousands of genes to regulate their expression in the nucleus (Raja et al. 2010). Human knockdown cell lines of central NSL components such as MOF contained reduced levels of mitochondrial transcripts and displayed a decreased translation rate of mitochondrial genes in vitro. Expression of a mitochondrion targeted MOF variant restores mitochondrial transcript levels and respiratory activity in the MOF knockdown cell lines (Chatterjee et al. 2016). The dual localization of the NSL complex points to a novel mechanism to fine-tune nuclear and mitochondrial gene expression. Finally, the stability of mRNA molecules can be modulated. Transcripts that are not used for translation are rapidly degraded. Several factors increase the stability of mRNA to promote protein synthesis. For instance, the Leu-rich pentatricopeptide motif-containing protein LRPPRC together with its partner protein, stem-loop-interacting RNA-binding protein (SLIRP), binds to mRNA molecules to prevent their degradation and stimulate their polyadenylation. In the absence of LRPPRC, orphan mRNAs are destabilized, leading to a reduction in gene expression and the neurodegenerative disease French Canadian type of Leigh syndrome (Sasarman et al. 2010; Chujo et al. 2012; Siira et al. 2017).

\section{Mitochondrial protein biosynthesis}

Mitochondria derived ribosomes from their bacterial progenitor. Recent structural analysis revealed several specific features of these mitoribosomes that are distinct from their bacterial counterparts (Amunts et al. 2015; Greber et al. 2015; Desai et al. 2017). Human mitoribosomes are composed of a $39 \mathrm{~S}$ large subunit and a $28 \mathrm{~S}$ small subunit and contain an unusually low ratio of ribonucleotides to proteins (30:70). They are composed of $\sim 80$ proteins and two ribosomal RNA (rRNA) molecules. Remarkably, about half of the mitoribosomal proteins are not present in bacterial ribosomes (Ott et al. 2016; Dennerlein et al. 2017). Proteomic and superresolution microscopy studies revealed that yeast mitoribosomes and proteins involved in post-transcriptional maturation of RNA molecules associate in large molecular structures, termed MIOREX (mitochondrial organization of gene expression) (Kehrein et al. 2015). Mitoribosomes are specialized for the synthesis of the membrane-bound respiratory chain subunits and therefore predominantly associate with the inner membrane. Specific receptor proteins mediate their attachment to the membrane. In yeast, Mba1, Oxa1 (oxidase assembly), and Mdm38 contribute to docking of mitoribosomes to the inner membrane (Jia et al. 2003; Szyrach et al. 2003; Frazier et al. 2006; Ott et al. 2006; Bauerschmitt et al. 2010; Pfeffer et al. 2015), while MRPL45 forms the inner membrane tether of human mitoribosomes (Greber et al. 2014). The membrane anchor brings the polypeptide exit tunnel of the mitoribosome in close proximity to the protein insertase Oxal that cotranslationally integrates mitochondrially encoded proteins into the inner membrane (Fig. 1; Hell et al. 2001).

\section{Yeast translational activators regulate mitochondrial translation}

In yeast, specific translational activators have been identified for all mitochondrial mRNA molecules (Table 1). The molecular mechanisms underlying how the translational activators stimulate protein synthesis are not well understood. Different functions have been assigned to the individual translational activators. Yeast mitochondrial transcripts contain a $5^{\prime}$ untranslated region (UTR) that is a target for translational regulation by translational activators. It has been shown that several translational activators act on the $5^{\prime}$ UTR of the transcript to promote translation of mitochondrial mRNAs, while other

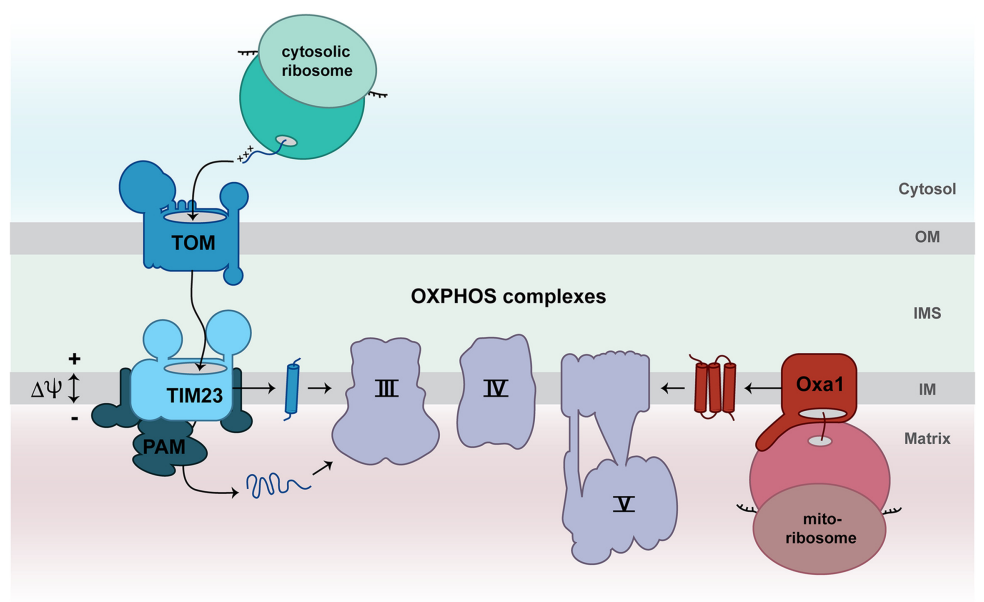

Figure 1. Biogenesis of mitochondrial respiratory chain subunits. The majority of nuclear-encoded subunits of the respiratory chain is synthesized by cytosolic ribosomes as precursors and imported into mitochondria via the translocase of the mitochondrial outer membrane (TOM complex) and the presequence translocase (TIM23 complex). Transport into the mitochondrial matrix additionally requires the ATP-dependent activity of the presequence translocase-associated motor (PAM). The membrane potential $(\Delta \psi)$ across the inner membrane drives protein translocation via the presequence pathway. The OXA1 complex inserts mitochondrially encoded subunits into the inner membrane in a cotranslational manner. Finally, mitochondrially encoded and nuclear-encoded subunits assemble into functional respiratory chain complexes. (IM) Inner membrane; (IMS) intermembrane space; (OM) outer membrane. 
translational activators stabilize transcripts or interact with ribosomes (Herrmann et al. 2013; Ott et al. 2016; Dennerlein et al. 2017; Timón-Gómez et al. 2018). Strikingly, superresolution microscopy and cryo-immunogold electron microscopy revealed that the translational activators of the cytochrome $b c_{1}$ complex, the cytochrome $c$ oxidase, and the ATP synthase colocalize with early assembly intermediates at the mitochondrial inner membrane (Stoldt et al. 2018). This observation indicates that the production of mitochondrial proteins is spatially linked to their assembly into mature protein machineries. Indeed, some translational activators are involved in the coordination of mitochondrial translation with the assembly of respiratory chain complexes as outlined below.

\section{The cytochrome $\mathrm{bc}_{1}$ complex}

The cytochrome $b c_{1}$ complex consists of 10 subunits in yeast and 11 subunits in human mitochondria. Crystal structures of the mammalian and yeast complex III have been reported (Xia et al. 1997; Iwata et al. 1998; Lange and Hunte 2002). The only mitochondrially encoded subunit, cytochrome $b$, is embedded via eight transmembrane spans into the inner membrane and contains two heme $b$ molecules that form reactive centers of the cytochrome $b c_{1}$ complex. The biogenesis of cytochrome $b$ is critical for the formation of mature complex III. The translational activators $\mathrm{Cbs} 1, \mathrm{Cbs} 2, \mathrm{Cbp} 1$, and the Cpb3/Cbp6 complex control the translation of $C O B$ mRNA encoding cytochrome $b$ in yeast mitochondria (Table 1 ; Ott et al. 2016; Dennerlein et al. 2017). Interestingly, the Cbp3/ Cbp6 complex is present in two pools. One population of $\mathrm{Cbp} 3 / \mathrm{Cbp} 6$ interacts with mitoribosomes in close proximity to the polypeptide exit tunnel to stimulate synthesis of cytochrome $b$ by an unknown mechanism (Gruschke et al. 2011; García-Guerrero et al. 2018). A second pool of $\mathrm{Cbp} 3 / \mathrm{Cbp} 6$ remains associated with cytochrome $b$ after its synthesis is completed to keep the protein in a conformation that allows insertion of the first heme $b$ molecule and binding of the assembly factor Cbp4 (Fig. 2; Gruschke et al. 2012; Hildenbeutel et al. 2014). The integration of the second heme $b$ molecule into cytochrome $b$ and the association of the first two nuclear-encoded complex III subunits (Qcr7 and Qcr8) contribute to the dissociation of $\mathrm{Cbp} 3 / \mathrm{Cbp} 6$ from the assembly intermediate (Gruschke et al. 2012; Hildenbeutel et al. 2014). Subsequently, further subunits assemble in a stepwise manner to form the mature cytochrome $b c_{1}$ complex (Fox 2012; Smith et al. 2012). The released Cbp3/Cbp6 complex in turn can stimulate a new round of translation of $C O B$ mRNA (Fig. 2; Gruschke et al. 2012). Upon failure of hemylation of cytochrome $b$ or impaired assembly with nuclear-encoded partner proteins, $\mathrm{Cbp} 3 / \mathrm{Cbp} 6$ remains associated with the intermediate and is not available to stimulate a further round of $C O B$ mRNA translation (Hildenbeutel et al. 2014). The Cbp3/Cbp6-mediated regulatory feedback loop is an elegant process to adapt cytochrome $b$ biosynthesis to the availability of heme and nuclear-encoded subunits of the cytochrome $b c_{1}$ complex.

\section{Cytochrome c oxidase}

Three mitochondrially encoded subunits (Cox1, Cox2, and Cox3) form the reactive core of complex IV and associate with nuclear-encoded proteins to form a functional cytochrome $c$ oxidase (Tsukihara et al. 1996). In yeast, specific translational activators control the synthesis of Cox1 (Mss51, Pet309, and Mam33), Cox2 (Pet111), and Cox3 (Pet54, Pet122, and Pet494) (Table 1; Herrmann et al. 2013; Ott et al. 2016; Dennerlein et al. 2017). The association of Cox1, Cox2, and Cox3 with nuclear-encoded subunits during formation of the cytochrome $c$ oxidase is a complicated process and involves $>30$ assembly factors (Fox 2012; Dennerlein et al. 2017; Timón-Gómez et al. 2018). The biogenesis of Cox1 is a key starting point for the de novo formation of complex IV. The protein is embedded into the inner membrane via 12 transmembrane segments and contains two heme $a$ molecules and one copper as prosthetic groups. Mss51 is a central regulator of Cox1 biogenesis. One pool of Mss51 binds to the $5^{\prime}$ UTR of the COX1 mRNA to stimulate its translation, while a second Mss51 fraction associates with newly synthesized Coxl that is already integrated into the inner membrane (Fig. 3; Decoster et al. 1990; Pérez-Martínez et al. 2003; Barrientos et al. 2004; Mick et al. 2010). Binding of Mss51 and the assembly factors Coa3 and Cox 14 protects the nascent Cox 1 from degradation. Upon inhibition of downstream assembly steps of complex IV, this intermediate form accumulates and sequesters Mss51 to down-regulate further translation of $C O X 1$ mRNA (Barrientos et al. 2004; Pérez-Martínez et al. 2009; Mick et al. 2010; Fontanesi et al. 2011). How Mss51 is released from the Cox1containing intermediate is not entirely understood. According to current models, the Shyl-mediated insertion

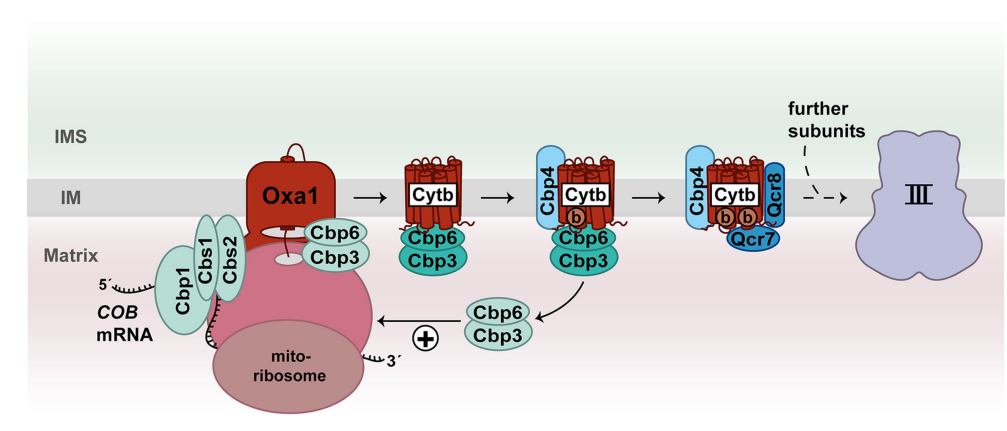

Figure 2. Feedbackloopregulation of cytochrome $b$ synthesis. The translational activators $\mathrm{Cbp} 1, \mathrm{Cbs} 1, \mathrm{Cbs} 2$, and Cbp3/Cbp6 promote the translation of $C O B$ mRNA to produce cytochrome $b(\mathrm{Cyt} \mathrm{b})$ in yeast mitochondria. The Cbp3/Cbp6 complex remains bound to membraneinserted cytochrome $b$ and facilitates insertion of heme $b$ and association of the assembly factor Cbp4. Binding of the nuclear-encoded subunits Qcr8 and Qcr7 as well as the insertion of the second heme $b$ molecule into cytochrome $b$ promote dissociation of the $\mathrm{Cbp} 3 / \mathrm{Cbp} 6 \mathrm{com}$ plex. The released Cbp3/Cbp6 complex can stimulate further rounds of translation of $C O B$ mRNA. (b) Heme $b$. 


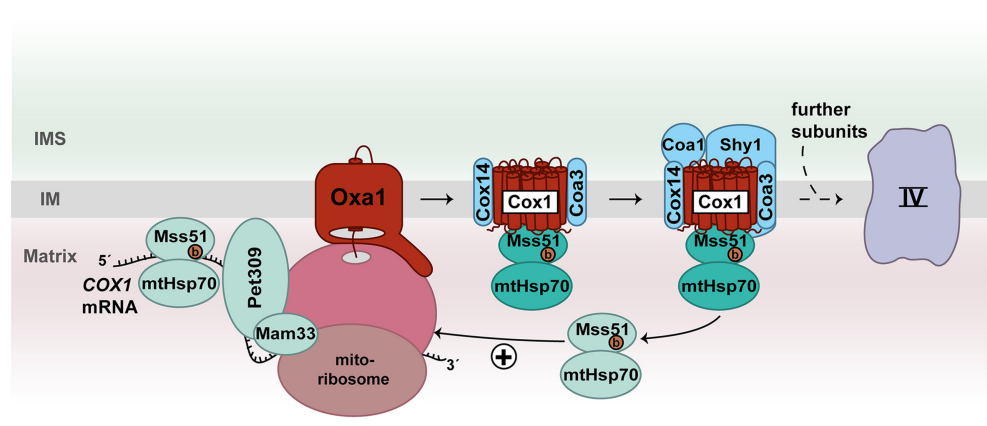

Figure 3. Feedback loop regulation of Cox1 synthesis. The translational activators Pet309, Mam33, and Mss51 promote translation of COX1 mRNA in yeast mitochondria. Mss51 as well as the assembly factors Cox 14 and Coa3 bind to membrane-inserted Cox 1 in an early assembly intermediate of complex IV. Both populations of Mss51 bind to $\mathrm{mtHsp} 70$. The biogenesis factors Coal and Shyl are added to the intermediate complex followed by association of the first nuclear-encoded subunits. At this stage, Mss51/mtHsp70 is released and can stimulate a new round of Coxl translation. (b) Heme $b$. of heme $a$ and the assembly of nuclear-encoded complex IV subunits Cox 5 a and Cox6 contribute to dissociation of Mss51 (Pérez-Martínez et al. 2009; Khalimonchuk et al. 2010; Mick et al. 2010; Fontanesi et al. 2011). The dynamic distribution of Mss51 couples mitochondrial translation of COX1 mRNA to the assembly status of the cytochrome $c$ oxidase (Fig. 3). Strikingly, the function of Mss51 as a translational activator of Cox1 depends on its bound heme $b$ cofactor (Soto et al. 2012). Thus, Mss51 could sense the mitochondrial heme content to fine-tune translation of COX1 mRNA (Soto et al. 2012). Altogether, synthesis of Cox 1 is tightly controlled by the availability of heme and its assembly with partner proteins.

\section{ATP synthase}

The ATP synthase consists of a matrix-located soluble $\mathrm{F}_{1}$ domain and membrane-integrated $F_{o}$ domain. The $F_{1}$ domain contains the catalytic centers and is linked via a central and peripheral stalk to the $\mathrm{F}_{\mathrm{o}}$ rotor domain (Rubinstein et al. 2003; Lau et al. 2008; Hahn et al. 2016; Guo et al. 2017). The overall composition of the ATP synthase in human and yeast mitochondria is largely similar ( $\mathrm{He}$ et al. 2018; Song et al. 2018). In yeast, the mitochondrial genome encodes ATP synthase subunits Atp6, Atp8, and Atp9. Ten Atp9 subunits form the $F_{0}$ rotor domain. The association of the $F_{o}$ rotor domain with Atp6 leads to the formation of the proton-conducting channel (Stock et al. 1999) and represents a critical step in the assembly of the ATP synthase (Rak et al. 2011; Naumenko et al. 2017). According to current models, formation of the proton-conducting channel of ATP synthase occurs in intermediate forms that contain the $\mathrm{F}_{1}$ domain and periph- eral stalk to prevent unimpeded proton leakage across the inner membrane. Consequently, the assembly process of the ATP synthase has to be strictly coordinated with the synthesis of mitochondrially encoded subunits (Rak et al. 2009; Fox 2012; Rühle and Leister 2015; Dennerlein et al. 2017). So far, little is known about the underlying molecular pathway. Interestingly, unassembled $\mathrm{F}_{1}$ domains stimulate the production of Atp6 and Atp8 by an unknown mechanism (Rak and Tzagoloff 2009). The protein Smt1 binds to the bicistronic ATP6/ATP8 mRNA to repress its translation (Rak et al. 2016). It was speculated that the unassembled $F_{1}$ domain could remove Smt1 from the mRNA, enabling the association of Atp22 that in turn stimulates synthesis of Atp6 and Atp8 (Fig. 4; Helfenbein et al. 2003; Rak et al. 2016). Future experimental work has to provide insights into the molecular mechanism by which Smt1 regulates translation of the ATP6/ ATP8 mRNA. The INA complex promotes the final formation of the proton-conducting channel by assembling the $\mathrm{F}_{\mathrm{o}}$ rotor domain with an Atp6/Atp8-containing module of the ATP synthase (Naumenko et al. 2017). Interestingly, in the absence of the INA complex, the in organello synthesis of Atp9 is reduced (Naumenko et al. 2017). Whether a molecular switch exists that controls the translation of ATP9 mRNA in response to the assembly stage of the ATP synthase remains to be investigated.

\section{Regulation of protein production in human mitochondria}

\section{Mitochondrial translational plasticity}

The control of mitochondrial protein synthesis in human cells is poorly understood. The transcripts in human

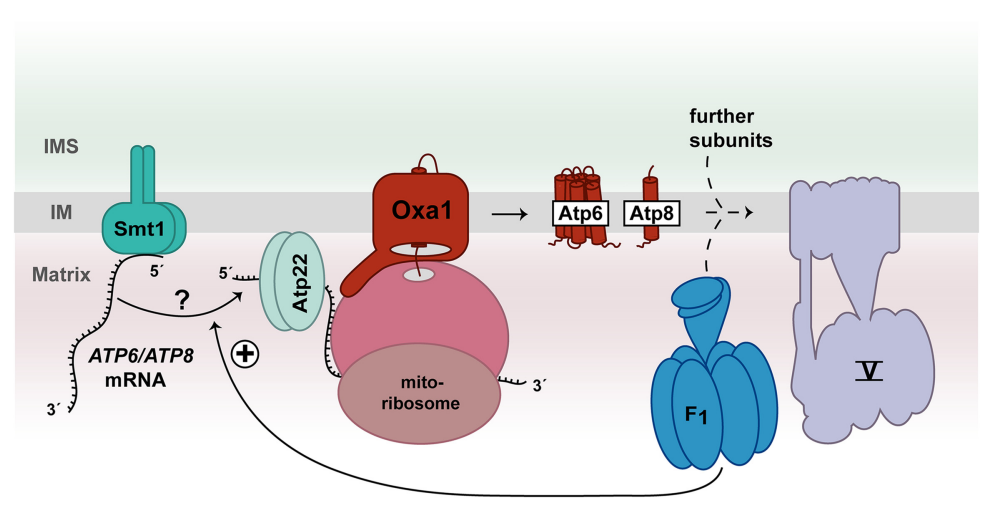

Figure 4. Model of feedback loop regulation of Atp6/ Atp8 synthesis. Yeast Smt1 represses the translation of the bicistronic ATP6/ATP8 mRNA. The unassembled $\mathrm{F}_{1}$ part of complex $\mathrm{V}$ may stimulate the release of Smt1 from ATP6/ATP8 mRNA by an unknown mechanism. Subsequently, Atp22 can bind to the mRNA to promote the translation of Atp6/Atp8 subunits. 
mitochondria either lack or contain only a short 5' UTR (Hällberg and Larsson 2014). The only known mitochondrial translational activator, TACO1, stimulates the synthesis of COX1 by an unknown mechanism. In contrast to yeast Mss51, TACO1 does not interact with COX1, which is present in assembly intermediates (Weraarpachai et al. 2009). Consequently, different modes exist to adjust protein production to the assembly of complex IV in human mitochondria. Recently, a novel mode of translational regulation of human COX1 mRNA was reported (Richter-Dennerlein et al. 2016). The assembly factor C12ORF62 (human COX14) binds to COX1, while it is produced on mitoribosomes. The binding of COX14 stalls the translation of COX1 mRNA (Richter-Dennerlein et al. 2016). Subsequently, mitochondrial translation regulation assembly intermediate of the cytochrome c oxidase 12 (MITRAC12; human COA3) associates with COX14 to stabilize the nascent chain of COX1 within the MITRAC complex (Fig. 5; Richter-Dennerlein et al. 2016; Bourens and Barrientos 2017). The translation of COX1 mRNA is paused within this complex until the first nuclear-encoded subunit, COX4-1 (homolog of yeast Cox6), is added to the assembly line (Richter-Dennerlein et al. 2016). The ability of mitoribosomes to adjust protein production to the assembly process of complex IV is termed translational plasticity (Richter-Dennerlein et al. 2016).

\section{MicroRNA molecules coordinate mitochondrial translation}

MicroRNAs such as miR-1 can regulate protein synthesis in human mitochondria (Zhang et al. 2014). In the cytoplasm, the microRNA miR-1 and the catalytic Argonaute protein AGO2 are part of the RNA-induced silencing complex (RISC) that binds target mRNAs to regulate their stability and translation. The partner protein GW182 recruits factors to the RISC that modify the bound mRNA to facilitate its degradation (Carthew and Sontheimer 2009; Czech and Hannon 2011). AGO2 and miR-1, but not GW182, have also been found in mitochondria. Here, the AGO2/miR-1 complex performs a different function. It binds to mitochondrial transcripts of several respiratory chain subunits to promote their translation. This microRNA-stimulated protein synthesis plays an important role in adjusting respiratory activity to the increased energy demand during muscle differentiation (Zhang et al. 2014). Interestingly, several additional microRNAs have been detected in mitochondria (Das et al. 2012; Sripada et al. 2012). Further studies are needed to investigate whether microRNAs play a more common role in regulating mitochondrial gene expression.

\section{Import of nuclear-encoded proteins into mitochondria}

Nuclear-encoded proteins destined for import into mitochondria are produced as precursors on cytosolic ribosomes. Molecular chaperones keep these preproteins in an unfolded import-competent state and guide them to receptors of the translocase of the outer mitochondrial membrane (TOM complex) (Young et al. 2003; Hoseini et al. 2016; Jores et al. 2018). The protein-conducting channel of the TOM complex mediates transport of the majority of precursor proteins across the outer membrane. Upon passage of the TOM channel, specific protein translocases sort the precursor proteins into the different mitochondrial subcompartments: the outer and inner membrane, the intermembrane space, and the matrix (Endo et al. 2011; Hewitt et al. 2011; Schleiff and Becker 2011; Neupert 2015; Wiedemann and Pfanner 2017). One exception is the integration of proteins with $a$-helical membrane anchors in the outer membrane that appear to occur independently of the TOM channel (Dukonovic and Rapaport 2011; Ellenrieder et al. 2015). In yeast, 70\% of mitochondrial proteins, including many respiratory chain subunits, are produced with a cleavable presequence and imported via the presequence translocase (TIM23 complex) into the inner membrane or matrix (Vögtle et al. 2009). The membrane potential across the inner mitochondrial membrane drives protein transport via the presequence pathway. Transport of preproteins into the mitochondrial matrix additionally requires ATP-dependent action of the presequence translocase-associated motor (PAM). The core subunit of the PAM machinery is the mitochondrial Hsp70 (mtHsp70) that powers protein

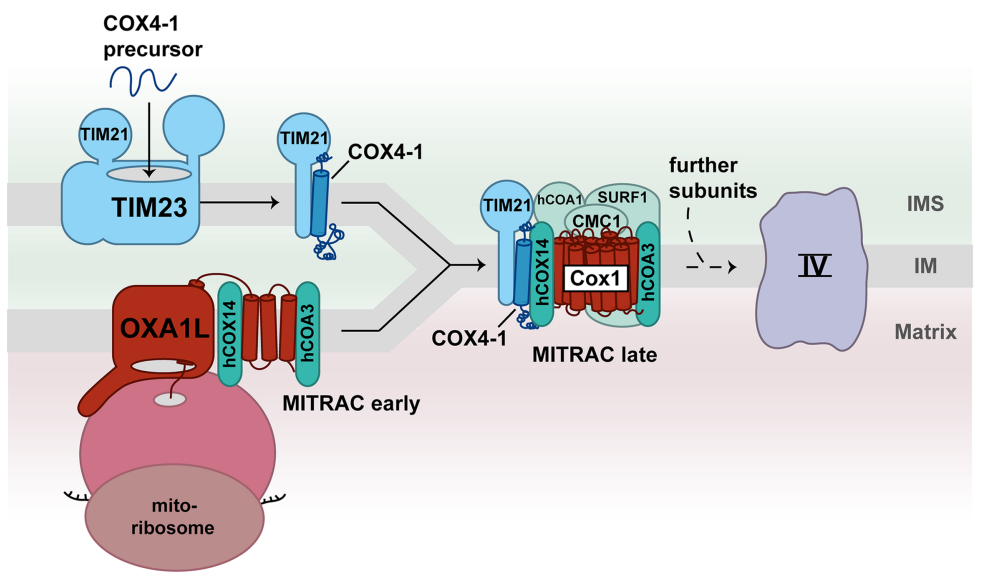

Figure 5. Coupling of protein import to the assembly of human complex IV. C12ORF62 (human COX14) and MITRAC12 (human COA3) bind to the nascent chain of COX1, forming the early MITRAC assembly intermediate in human mitochondria. The translation of COX1 mRNA on mitoribosomes is paused within this complex. The assembly of the first nuclear-encoded subunit, COX4-1, leads to completion of COX1 translation. The presequence translocase subunit TIM21 delivers the COX4-1 precursor from the TIM23 complex to the MITRAC assembly intermediate. Additional assembly factors such as MITRAC15 (human COA1), CMC1, and SURF1 (homolog to yeast Shy1) are added to form the late MITRAC assembly intermediate. 
transport into the matrix by ATP hydrolysis (Endo et al. 2011; Hewitt et al. 2011; Schleiff and Becker 2011; Neupert 2015; Wiedemann and Pfanner 2017).

\section{Coupling of protein import to respiratory chain biogenesis}

The import of nuclear-encoded proteins is closely linked to the activity and assembly of respiratory chain complexes. In yeast, the supercomplex of the cytochrome $b c_{1}$ complex and cytochrome $c$ oxidase interacts with the TIM23 complex and the Pam16/Pam18 module (van der Laan et al. 2006; Wiedemann et al. 2007). According to the current model, the presequence translocase-associated respiratory chain complexes locally establish a high membrane potential to promote import of precursor proteins via the TIM23 complex (van der Laan et al. 2006). Interestingly, the import of some precursor proteins such as Atp2 of the ATP synthase appears to be hypersensitive toward perturbations of the membrane potential (Schendzielorz et al. 2017). Whether the coupling between the TIM23 complex and the respiratory chain in particular stimulates the import of these substrates remains to be shown.

Components of the PAM machinery promote assembly of respiratory chain subunits in yeast mitochondria as well. The mitochondrial chaperone mtHsp70 is involved in the formation of respiratory chain complexes via two independent mechanisms. First, mtHsp70 robustly interacts with Mss51 and thereby contributes to the regulation of COX1 mRNA translation (Fig. 2; Fontanesi et al. 2010). Second, the complex IV subunit Cox4 was identified as a major interaction partner of $\mathrm{mtHsp} 70$ in affinity purifications (Böttinger et al. 2013). The addition of Cox4 to assembly intermediates is a critical step in the formation of the mature cytochrome $c$ oxidase (Frazier et al. 2006; Böttinger et al. 2013). Interestingly, Cox4 accumulates at mtHsp70 when the formation of the cytochrome $c$ oxidase is blocked. Thus, mtHsp70-bound Cox 4 represents a reservoir of free Cox 4 that can be delivered into the assembly line when needed (Böttinger et al. 2013). Similarly, assembly intermediates of Cox 1 and cytochrome $b$ can be detected under physiological conditions (Mick et al. 2010; Hildenbeutel et al. 2014). The association of different assembly factors and chaperones keeps the core subunits in an assembly-competent state. Therefore, the presence of such key intermediates could ensure rapid formation of mitochondrial respiratory chain complexes. Such a mechanism could enable yeast cells to rapidly adapt to respiratory growth conditions.

In human mitochondria, TIM21 plays a direct role in the formation of respiratory chain complexes via its interaction with two protein machineries. On one hand, TIM21 is a subunit of the TIM23 translocase; on the other hand, it associates with MITRAC that forms a platform for the assembly of the cytochrome $c$ oxidase (Mick et al. 2012). TIM21 shuttles nuclear-encoded subunits from the TIM23 complex to MITRAC to promote formation of complex IV (Fig. 5). Supporting this model, the assembly of COX4-1 was strongly affected in mitochondria from TIM21 knockdown cells (Mick et al. 2012). The addi- tion of COX4-1 to the MITRAC intermediate is critical to complete the translation of COX1 mRNA as described above (Richter-Dennerlein et al. 2016). Therefore, the TIM21-mediated delivery of COX4-1 represents a crucial step in the formation of cytochrome $c$ oxidase and establishes an intriguing connection between the protein import machinery and mitochondrial protein biosynthesis. Altogether, in both human and yeast mitochondria, components of the TIM23 complex are closely linked to the assembly pathway of the respiratory chain.

\section{Regulation of mitochondrial protein import}

Many signaling pathways mediate the communication between mitochondria and the nucleus under different physiological and stress conditions (Ryan and Hoogenraad 2007; Quirós et al. 2016). Protein translocases represent a major target for the control of mitochondrial function. More than 30 phosphorylation sites have been identified in the TOM complex of yeast mitochondria (Schmidt et al. 2011). Phosphorylation by proteinase A (PKA) modulates protein import in response to metabolic changes. Shifting yeast cells from respiratory to fermentable growth leads to activation of PKA. It has been reported that PKA phosphorylates precursors of TOM components and thereby impairs the formation of the TOM complex (Rao et al. 2012; Gerbeth et al. 2013). Furthermore, PKA phosphorylates the import receptor Tom 70, which affects import of hydrophobic precursor proteins such as metabolite carriers (Schmidt et al. 2011; Gerbeth et al. 2013). Cyclin-dependent kinase Cdc28 phosphorylates the small TOM subunit Tom6 during the G2-M transition in the cell cycle, which in turn modulates the assembly of the TOM complex (Harbauer et al. 2014). Altogether, phosphorylation of TOM proteins regulates function and assembly of the TOM complex to adapt protein import to specific requirements during metabolic changes or the cell cycle (Schmidt et al. 2011; Gerbeth et al. 2013; Harbauer et al. 2014). Moreover, the efficiency of TIM23-mediated protein import can be modulated upon cellular stress signaling. In human cells, arsenite-induced stress causes a reduction of TIM17A levels. Since TIM17A is an essential component of the TIM23 complex, decreased content of this subunit impairs protein transport into mitochondria (Rainbolt et al. 2013). These observations established protein translocases as central targets for regulation of protein import into mitochondria in response to cellular signaling.

\section{Role of protein import in mitochondrial stress responses}

Different pathways have been described to address how impaired protein import modulates cytosolic protein homeostasis by retrograde signaling. Yeast mutants that are defective in protein import display an increased proteasomal activity to degrade nonimported precursor proteins, which is termed unfolded protein response (UPR) activated by mistargeting of proteins (UPRam) (Wrobel et al. 2015). In addition, cytosolic protein biosynthesis is 
modulated upon mitochondrial precursor overaccumulation stress (mPOS). The CAP-dependent translation on cytosolic ribosomes is decreased (Wang and Chen 2015; Wrobel et al. 2015), while the Gis2-promoted CAP-independent translation of specific mRNAs is stimulated to maintain cell survival (Wang and Chen 2015). Reactive oxygen could play an important role in this response pathway. Defects in protein import lead to increased levels of reactive oxygen species, which in turn affect protein synthesis by modification of cytosolic ribosomes (Topf et al. 2018). Finally, a control mechanism at the mitochondrial surface has been reported. Overexpression of mitochondrial precursor proteins leads to a partial block of protein import and activation of the mitochondrial compromised protein import response (mitoCPR). In the mitoCPR pathway, the transcription factor Pdr3 induces expression of CIS1 (Weidberg and Amon 2018). The cytosolic protein Cis1 binds to the Tom70 receptor and Msp1. The AAA ATPase Msp1 removes accumulated precursor proteins from the mitochondrial outer membrane for proteasomal degradation (Weidberg and Amon 2018). Msp1 also extracts mistargeted ER and peroxisomal tail-anchored proteins from the mitochondrial outer membrane (Chen et al. 2014; Okreglak and Walter 2014; Weir et al. 2017). Thus, Msp1 plays a central role to prevent an overload of mitochondria with mislocalized proteins. Altogether, distinct protective mechanisms take place in the cytosol and on the mitochondrial surface to alleviate damage due to mitochondrial protein import. The challenge of future research will be the identification of molecular players and mechanisms of the different protective stress response pathways.

In the nematode Caenorhabditis elegans, an elegant mechanism has been identified demonstrating how mitochondrial damage induces the mitochondrial UPR $\left(\mathrm{UPR}^{\mathrm{mt}}\right.$ ) (Nargund et al. 2012; Higuchi-Sanabria et al. 2018; Samluk et al. 2018; Shpilka and Haynes 2018). The cellular localization of the transcription factor ATFS- 1 is pivotal for the induction of the UPR ${ }^{\mathrm{mt}}$. ATFS1 contains a mitochondrial and a nuclear targeting signal. In intact mitochondria, the protein is imported into the matrix and degraded by the protease LON. Upon mitochondrial damage, the import of ATFS-1 is impaired, and the transcription factor relocalizes to the nucleus (Nargund et al. 2012). In the nucleus, ATFS-1 and the transcriptional regulators DVE-1 and UBL-5 induce the expression of genes encoding mitochondrial chaperones and proteases to protect mitochondria against oxidative damage (Fig. 6; Benedetti et al. 2006; Haynes et al. 2007; Tian et al. 2016). In addition, ATFS-1 down-regulates the expression of oxidative phosphorylation (OXPHOS) genes in the nucleus and in mitochondria to facilitate recovery of the cell organelle (Fig. 6; Nargund et al. 2015). In mammals, the three transcription factors ATFS-4, ATFS-5, and CHOP are involved in the induction of the UPR ${ }^{\mathrm{mt}}$ by an unknown mechanism (Higuchi-Sanabria et al. 2018; Samluk et al. 2018; Shpilka and Haynes 2018). Expression of human ATFS-5 can compensate for the loss of ATFS-1 in worms, indicating that basic mechanisms to induce the $\mathrm{UPR}^{\mathrm{mt}}$ are conserved between worms and humans

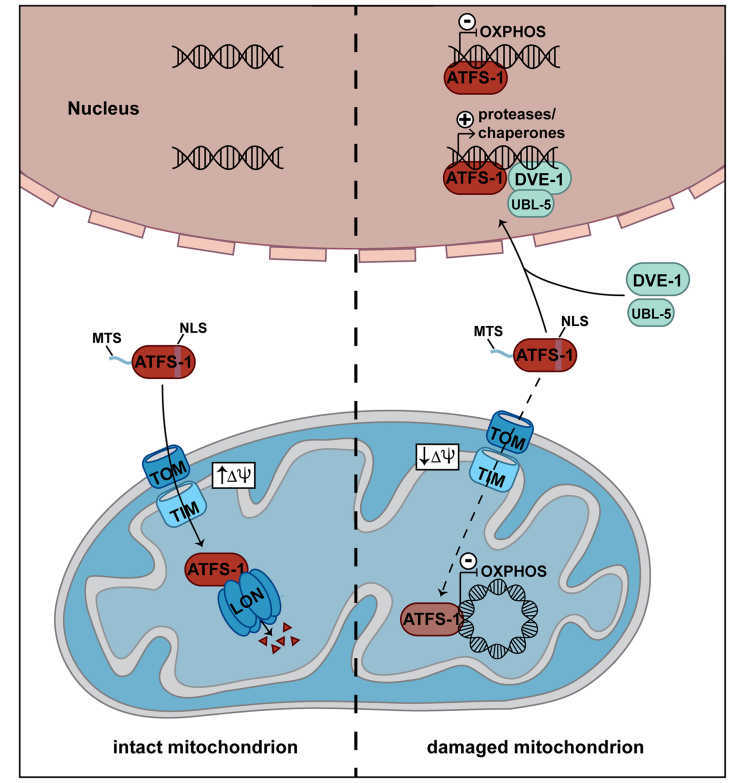

Figure 6. Defects in mitochondrial protein import induce the $\mathrm{UPR}^{\mathrm{mt}}$. In C. elegans, the transcription factor ATFS-1 contains a mitochondrial (MTS) and a nuclear (NLS) targeting signal. The TOM and TIM23 complexes transport ATFS- 1 into the matrix of intact mitochondria, where it is degraded by the LON protease. In damaged mitochondria, the membrane potential $(\Delta \psi)$ is diminished, and the import of ATFS-1 into mitochondria is impaired. Instead, a fraction of ATFS-1 relocalizes to the nucleus. Together with the transcription factors DVE-1 and UBL-5, it induces the transcription of genes involved in the UPR ${ }^{\mathrm{mt}}$. In addition, uncharacterized fractions of ATFS-1 silence the expression of nuclear and mitochondrial OXPHOS genes.

(Fiorese et al. 2016). All of these different examples illustrate that protein import exerts a dual role as a target of regulation and as a sensor for mitochondrial damage to induce cellular stress responses by retrograde signaling.

\section{Conclusion}

Balancing mitochondrial and cytoplasmic protein production is crucial for building up respiratory chain complexes and is therefore of central importance for cellular metabolism. Mitochondrial protein biogenesis and import of nuclear-encoded proteins are central targets of regulation. A few mechanisms such as translational plasticity and regulatory feedback loops via translational activators have been discovered that fine-tune mitochondrial protein biogenesis to the assembly process of respiratory chain complexes. The presence of additional translation factors in yeast mitochondria leads to the question of whether similar negative feedback loops such as those for Cox1 and cytochrome $b$ exist for all mitochondrially encoded proteins. Regulation is likely even more complex, since cross-talk between the different assembly lines appears to occur (Mick et al. 2012; Mayorga et al. 2016). This observation indicates that a dynamic network of biogenesis factors may balance the formation of different respiratory chain 
complexes. In addition, import of nuclear-encoded proteins is closely linked to the assembly lines of respiratory chain complexes. Supporting this view, the initial assembly steps of complex III and complex IV occur primarily in the inner boundary membrane, where TIM23 complexes are also enriched (Vogel et al. 2006; Stoldt et al. 2018). We propose that coupling of protein import and mitochondrial protein biogenesis is a key mechanism to coordinate the assembly of respiratory chain complexes. We further suggest that import of nuclear-encoded proteins plays a dual role in controlling mitochondrial protein homeostasis. On one hand, protein translocases are a central target for regulation via phosphorylation; on the other hand, import pathways are critical to induce stress response pathways upon mitochondrial damage. In conclusion, recent studies indicate that a number of different pathways coordinate the protein biosynthesis in mitochondria and the cytosol.

\section{Acknowledgments}

This work was funded by grants of the Deutsche Forschungsgemeinschaft (BE4679/2-1), Sonderforschungsbereich 746, Research Training Group 2202, and the Excellence Initiative of the German Federal and State Governments (EXC 294 BIOSS).

\section{References}

Amunts A, Brown A, Toots J, Scheres SHW, Ramakrishnan V. 2015. The structure of the human mitochondrial ribosome. Science 348: 95-98.

Archibald JM. 2015. Endosymbiosis and eukaryotic cell evolution. Curr Biol 25: 911-921.

Barrientos A, Zambrano A, Tzagoloff A. 2004. Mss51p and Cox $14 \mathrm{p}$ jointly regulate mitochondrial Cox $1 \mathrm{p}$ expression in Saccharomyces cerevisiae. EMBO J 23: 3472-3482.

Battey J, Clayton DA. 1978. The transcription map of mouse mitochondrial DNA. Cell 14: 143-156.

Bauerschmitt H, Mick DU, Deckers M, Vollmer C, Funes S, Kehrein K, Ott M, Rehling P, Herrmann JM. 2010. Ribosome-binding proteins $\mathrm{Mdm} 38$ and Mbal display overlapping functions for regulation of mitochondrial translation. Mol Biol Cell 21: 1937-1944.

Benedetti C, Haynes CM, Yang Y, Harding HP, Ron D. 2006. Ubiquitin-like protein 5 positively regulates chaperone gene expression in the mitochondrial unfolded protein response. Genetics 174: 229-239.

Böttinger L, Horvath SE, Kleinschroth T, Hunte C, Daum G, Pfanner N, Becker T. 2012. Phosphatidylethanolamine and cardiolipin differently affect the stability of mitochondrial respiratory chain supercomplexes. J Mol Biol 423: 677-686.

Böttinger L, Guiard B, Oeljeklaus S, Kulawiak B, Zufall N, Wiedemann N, Warscheid B, van der Laan M, Becker T. 2013. A complex of Cox 4 and mitochondrial Hsp70 plays an important role in the assembly of the cytochrome $c$ oxidase. Mol Biol Cell 24: 2609-2619.

Bourens M, Barrientos A. 2017. A CMC1-knockout reveals translation-independent control of human mitochondrial complex IV biogenesis. EMBO Rep 18: 477-494.

Carthew RW, Sontheimer EJ. 2009. Origins and mechanisms of miRNAs and siRNAs. Cell 136: 642-655.
Chatterjee A, Seyfferth J, Lucci J, Gilsbach R, Preissl S, Böttinger L, Mårtensson CU, Panhale A, Stehle T, Kretz O, et al. 2016. MOF acetyl transferase regulates transcription and respiration in mitochondria. Cell 167: 722-738.

Chen YC, Umanah GK, Dephoure N, Andrabi SA, Gygi SP, Dawson TM, Rutter J. 2014. Msp1/ATAD1 maintains mitochondrial functions by facilitating the degradation of mislocalized tail-anchored proteins. EMBO J 33: 1548-1564.

Chujo T, Ohira T, Sakaguchi Y, Goshima N, Nomura N, Nagao A, Suzuki T. 2012. LRPPRC/SLIRP suppresses PNPase-mediated mRNA decay and promotes polyadenylation in human mitochondria. Nucleic Acids Res 40: 8033-8047.

Couvillion MT, Soto IC, Shipkovenska G, Churchman LS. 2016. Synchronized mitochondrial and cytosolic translation programs. Nature 533: 499-503.

Cruciat CM, Brunner S, Baumann F, Neupert W, Stuart RA. 2000. The cytochrome $b c_{1}$ and cytochrome $c$ oxidase complexes associate to form a single supracomplex in yeast mitochondria. J Biol Chem 275: 18093-18098.

Czech B, Hannon GJ. 2011. Small RNA sorting: matchmaking for Argonautes. Nat Rev Genet 12: 19-31.

Das S, Ferlito M, Kent OA, Fox-Talbot K, Wang R, Liu D, Raghavachari N, Yang Y, Wheelan SI, Murphy E, et al. 2012. Nuclear miRNA regulates the mitochondrial genome in the heart. Circ Res 110: 1596-1603.

Decoster E, Simon M, Hatat D, Faye G. 1990. The MSS51 gene product is required for the translation of the COX1 mRNA in yeast mitochondria. Mol Gen Genet 224: 111-118.

Dennerlein S, Wang C, Rehling P. 2017. Plasticity of mitochondrial translation. Trends Cell Biol 27: 712-721.

Desai N, Brown A, Amunts A, Ramakrishnan V. 2017. The structure of the yeast mitochondrial ribosome. Science 355: 528531.

Dukonovic J, Rapaport D. 2011. Multiple pathways in the integration of proteins into the mitochondrial outer membrane. Biochim Biophys Acta 1808: 971-980.

Ellenrieder L, Mårtensson CU, Becker T. 2015. Biogenesis of mitochondrial outer membrane proteins, problems and diseases. Biol Chem 396: 1199-1213.

Endo T, Yamano K, Kawano S. 2011. Structural insight into the mitochondrial protein import system. Biochim Biophys Acta 1808: 955-970.

Fiorese CJ, Schulz AM, Lin YF, Rosin N, Pllegrina MW, Haynes CM. 2016. The transcription factor ATF5 mediates a mammalian mitochondrial UPR. Curr Biol 26: 2037-2043.

Fontanesi F, Soto IC, Horn D, Barrientos A. 2010. Mss51 and Ssc1 facilitate translational regulation of cytochrome $c$ oxidase biogenesis. Mol Cell Biol 30: 245-259.

Fontanesi F, Clemente P, Barrientos A. 2011. Cox25 teams up with Mss51, Ssc1, and Cox14 to regulate mitochondrial cytochrome $c$ oxidase subunit 1 expression and assembly in Saccharomyces cerevisiae. I Biol Chem 286: 555-566.

Fox TD. 2012. Mitochondrial protein synthesis, import and assembly. Genetics 192: 1203-1234.

Frazier AE, Taylor RD, Mick DU, Warscheid B, Stoepel N, Meyer HE, Ryan MT, Guiard B, Rehling P. 2006. Mdm38 interacts with ribosomes and is a component of the mitochondrial protein export machinery. J Cell Biol 172: 553-564.

García-Guerrero AE, Camacho-Villasana Y, Zamudio-Ochoa A, Pérez-Martínez X. 2018. Cbp3 and Cbp6 are dispensable for synthesis regulation of cytochrome $b$ in yeast mitochondria. I Biol Chem 293: 5585-5599.

Gerbeth C, Schmidt O, Rao S, Harbauer AB, Mikropoulou D, Opalińska M, Guiard B, Pfanner N, Meisinger C. 2013. Glucose-induced regulation of protein import receptor Tom 22 
by cytosolic and mitochondria-bound kinases. Cell Metab 18: 578-587.

Greber BJ, Boehringer D, Leitner A, Bieri P, Voigs-Hoffmann F, Erzberger JP, Leibundgut M, Aebersold R, Ban N. 2014. Architecture of the large subunit of the mammalian mitochondrial ribosome. Nature 505: 515-519.

Greber BJ, Bieri P, Leibundgut M, Leitner A, Aebersold R, Boehringer D, Ban N. 2015. The complete structure of the $55 \mathrm{~S}$ mammalian mitochondrial ribosome. Science 348: 303-308.

Gruschke S, Kehrein K, Römpler K, Gröne K, Israel L, Imhof A, Herrmann JM, Ott M. 2011. Cbp3-Cbp6 interacts with the yeast mitochondrial ribosomal tunnel exit and promotes cytochrome $b$ synthesis and assembly. J Cell Biol 193: 1101-1114.

Gruschke S, Römpler K, Hildenbeutel M, Kehrein K, Kühl I, Bonnefoy N, Ott M. 2012. The Cbp3-Cbp6 complex coordinates cytochrome $b$ synthesis with $b c 1$ complex assembly in yeast mitochondria. J Cell Biol 199: 137-150.

Gu J, Wu M, Guo R, Yan K, Lei J, Gao N, Yang M. 2016. The architecture of the mammalian respirasome. Nature 537: 639-643.

Guo H, Bueler SA, Rubinstein JL. 2017. Atomic model for the dimeric $F_{0}$ region of mitochondrial ATP synthase. Science 358: 936-940.

Hahn A, Parey K, Bublitz M, Mills DJ, Zickermann V, Vonck J, Kühlbrandt W, Meier T. 2016. Structure of a complete ATP synthase dimer reveals the molecular basis of inner mitochondrial membrane morphology. Mol Cell 63: 445-456.

Hällberg BM, Larsson NG. 2014. Making proteins in the powerhouse. Cell Metab 20: 226-240.

Harbauer AB, Opalińska M, Gerbeth C, Herman JS, Rao S, Schönfisch B, Guiard B, Schmidt O, Pfanner N, Meisinger C. 2014. Cell cycle-dependent regulation of mitochondrial preprotein translocase. Science 346: 1109-1113.

Haynes CM, Petrova K, Benedetti C, Yang Y, Ron D. 2007. ClpP mediates activation of a mitochondrial unfolded protein response in C. elegans. Dev Cell 13: 467-480.

He J, Ford HC, Carroll J, Douglas C, Gonzales E, Ding S, Fearnley IM, Walker JE. 2018. Assembly of the membrane domain of ATP synthase in human mitochondria. Proc Natl Acad Sci 115: 2988-2993.

Helfenbein KG, Ellis TP, Dieckmann CL, Tzagoloff A. 2003. ATP22, a nuclear gene required for expression of the $\mathrm{F}_{\mathrm{o}}$ sector of mitochondrial ATPase in Saccharomyces cerevisiae. J Biol Chem 278: 19751-19756.

Hell K, Neupert W, Stuart RA. 2001. Oxalp acts as general membrane insertion machinery for proteins encoded by mitochondrial DNA. EMBO / 20: 1281-1288.

Herrmann JM, Woellhaf MW, Bonnefoy N. 2013. Control of protein synthesis in yeast mitochondria: the concept of translational activators. Biochim Biophys Acta 1833: 286-294.

Hewitt V, Alcock F, Lithgow T. 2011. Minor modifications and major adaptations: the evolution of molecular machines driving mitochondrial protein import. Biochim Biophys Acta 1808: 947-954.

Higuchi-Sanabria R, Frankino PA, Paul JW III, Tronnes SU, Dillin A. 2018. A futile battle? Protein quality control and the stress of aging. Dev Cell 44: 139-163.

Hildenbeutel M, Hegg EL, Stephan K, Gruschke S, Meunier B, Ott M. 2014. Assembly factors monitor sequential hemylation of cytochrome $b$ to regulate mitochondrial translation. I Cell Biol 205: 511-524.

Hoseini H, Pandey S, Jores T, Schmitt A, Franz-Wachtel M, Macek B, Buchner J, Dimmer KS, Rapaport D. 2016. The cytosolic cochaperone Stil is relevant for mitochondrial biogenesis and morphology. FEBS J 283: 3338-3352.
Iwata S, Lee SW, Okada K, Lee JK, Iwata M, Rasmussen B, Link TA, Ramaswamy S, Jap BK. 1998. Complete structure of the 11-subunit bovine mitochondrial cytochrome $b c_{1}$ complex. Science 281: 64-71.

Jia L, Dienhart M, Schramp M, McCauley M, Hell K, Stuart RA. 2003. Yeast Oxal interacts with mitochondrial ribosomes: the importance of the C-terminal region of Oxa1. EMBO $J$ 22: 6438-6447.

Jores T, Lawatscheck J, Beke V, Franz-Wachtel M, Yunoki K, Fitzgerald JC, Macek B, Endo T, Buchner J, Rapaport D. 2018. Cytosolic Hsp70 and Hsp40 chaperones enable the biogenesis of mitochondrial $\beta$-barrel proteins. J Cell Biol 217: 3091-3108.

Kehrein K, Schilling R, Möller-Hergt BV, Wurm CA, Jakobs S, Lamkemeyer T, Langer T, Ott M. 2015. Organization of mitochondrial gene expression in two distinct ribosome-containing assemblies. Cell Rep 10: 843-853.

Khalimonchuk O, Bird A, Winge DR. 2007. Evidence for a pro-oxidant intermediate in the assembly of the cytochrome oxidase. J Biol Chem 282: 17442-17449.

Khalimonchuk O, Bestwick M, Meunier B, Watts TC, Winge DR. 2010. Formation of the redox cofactor centers during Cox 1 maturation in yeast cytochrome oxidase. Mol Cell Biol 30: 1004-1017.

Lange C, Hunte C. 2002. Crystal structure of the yeast cytochrome $b c_{1}$ complex with its bound substrate cytochrome $c$. Proc Natl Acad Sci 99: 2800-2805.

Lau WC, Baker LA, Rubinstein JL. 2008. Cryo-EM structure of the yeast ATP synthase. J Mol Biol 382: 1256-1264.

Letts JA, Fiedorczuk K, Sazanov LA. 2016. The architecture of respiratory supercomplexes. Nature 537: 644-648.

Luttik MA, Overkamp KM, Kötter P, de Vries S, van Dijken JP, Pronk JT. 1998. The Saccharomyces cerevisiae NDE1 and NDE2 genes encode separate mitochondrial NADH dehydrogenases catalyzeing the oxidation of cytosolic NADH. I Biol Chem 273: 24529-24534.

Marres CA, de Vries S, Grivell LA. 1991. Isolation and inactivation of the nuclear gene encoding the rotenone-insensitive internal NADH: ubiquinone oxidoreductase of mitochondria from Saccharomyces cerevisiae. Eur J Biochem 195: 857-862.

Mayorga JP, Camacho-Villasana Y, Shingú-Vázquez M, GarciaVillegas R, Ramudio-Ochoa A, García-Guerrero AE, Hernández G, Pérez-Martínez X. 2016. A novel function of Pet54 in regulation of Cox1 synthesis in Saccharomyces cerevisiae. I Biol Chem 291: 9343-9355.

Mick DU, Vukotic M, Piechura H, Meyer HE, Warscheid B, Deckers M, Rehling P. 2010. Coa3 and Cox14 are essential for negative feedback regulation of COX1 translation in mitochondria. J Cell Biol 191: 141-154.

Mick DU, Dennerlein S, Wiese H, Reinhold R, Pacheu-Grau D, Lorenzi I, Sasaran F, Weraarpachai W, Shoubridge EA, Warscheid B, et al. 2012. MITRAC links mitochondrial protein translocation to respiratory-chain assembly and translational regulation. Cell 151: 1528-1541.

Morgenstern M, Stiller SB, Lübbert P, Peikert CD, Dannenmaier S, Drepper F, Weil U, Höß P, Feuerstein R, Gebert M, et al. 2017. Definition of a high-confidence mitochondrial proteome at quantitative scale. Cell Rep 19: 2836-2852.

Nargund AM, Pellegrino MW, Fiorese CJ, Baker BM, Haynes CM. 2012. Mitochondrial import efficiency of ATFS-1 regulates mitochondrial UPR activation. Science 337: 587-590.

Nargund AM, Fiorese CJ, Pellegrino MW, Deng P, Haynes CM. 2015. Mitochondrial and nuclear accumulation of the transcription factor ATFS-1 promotes OXPHOS recovery during $\mathrm{UPR}^{\mathrm{mt}}$. Mol Cell 58: 123-133. 
Naumenko N, Morgenstern M, Rucktäschel R, Warscheid B, Rehling P. 2017. INA complex liaises the $F_{1} F_{0}$-ATP synthase membrane motor modules. Nat Commun 8: 1237.

Neupert W. 2015. A perspective on transport of proteins into mitochondria: a myriad of open questions. I Mol Biol 427: 1135-1158.

Okreglak V, Walter P. 2014. The conserved AAA-ATPase Msp1 confers organelle specificity to tail-anchored proteins. Proc Nat1 Acad Sci 111: 8019-8024.

Ott M, Prestele M, Bauerschmitt H, Funes S, Bonnefoy N, Herrmann JM. 2006. Mbal, a membrane-associated ribosome receptor in mitochondria. EMBO J 25: 1603-1610.

Ott M, Amunts A, Brown A. 2016. Organization and regulation of mitochondrial protein synthesis. Annu Rev Biochem 85: 77-101.

Pagliarini DJ, Calvo SE, Chang B, Sheth SA, Vafai SB, Ong SE, Walford GA, Sugiana C, Boneh A, Chen WK, et al. 2008. A mitochondrial protein compendium elucidates complex I disease biology. Cell 134: 112-123.

Pearce SF, Rebelo-Guiomar P, D'Souza AR, Powell CA, van Haute L, Minczuk M. 2017. Regulation of mammalian mitochondrial gene expression: recent advances. Trends Biochem Sci 42: 625-639.

Pérez-Martínez X, Broadley SA, Fox TD. 2003. Mss51p promotes mitochondrial Coxlp synthesis and interacts with newly synthesized Coxlp. EMBO I 22: 5951-5961.

Pérez-Martínez X, Butler CA, Shingu-Vazquez M, Fox TD. 2009. Dual functions of Mss51 couple synthesis of Cox1 to assembly of cytochrome $c$ oxidase in Saccharomyces cerevisiae mitochondria. Mol Biol Cell 20: 4371-4380.

Pfeffer S, Woellhaf MW, Herrmann JM, Förster F. 2015. Organization of the mitochondrial translation machinery studied in situ by cryoelectron tomography. Nat Commun 6: 6019.

Quirós PM, Mottis A, Auwerx J. 2016. Mitonuclear communication in homeostasis and stress. Nat Rev Mol Cell Biol 17: 213-226.

Rainbolt TK, Atanassova N, Genereux JC, Wiseman RL. 2013. Stress-regulated translational attenuation adapts mitochondrial protein import through TIM17A. Cell Metab 18: 908-919.

Raja SJ, Charapitsa I, Conrad T, Vaquerizas JM, Gebhardt P, Holz H, Kadlec J, Fraterman S, Luscombe NM, Akhtar A. 2010. The nonspecific lethal complex is a transcriptional regulator in Drosophila. Mol Cell 38: 827-841.

Rak M, Tzagoloff A. 2009. $\mathrm{F}_{1}$-dependent translation of mitochondrially encoded Atp6p and Atp8p subunits of yeast ATP synthase. Proc Natl Acad Sci 106: 18509-18514.

Rak M, Zeng X, Brière JJ, Tzagoloff A. 2009. Assembly of $F_{o}$ in Saccharomyces cerevisiae. Biochim Biophys Acta 1793: 108-116.

Rak M, Gokova S, Tzagoloff A. 2011. Modular assembly of yeast mitochondrial ATP synthase. EMBO J 30: 920-930.

Rak M, Su CH, Xu JT, Azpiroz R, Singh AM, Tzagoloff A. 2016. Regulation of mitochondrial translation of the ATP8/ATP6 mRNA by Smt1p. Mol Biol Cell 27: 919-929.

Rao S, Schmidt O, Harbauer AB, Schönfisch B, Guiard B, Pfanner N, Meisinger C. 2012. Biogenesis of the preprotein translocase of the outer mitochondrial membrane: protein kinase A phosphorylates the precursor of Tom 40 and impairs its import. Mol Biol Cell 23: 1618-1627.

Richter-Dennerlein R, Oeljeklaus S, Lorenzi I, Ronsör C, Bareth B, Schendzielorz AB, Wang C, Warscheid B, Rehling P, Dennerlein S. 2016. Mitochondrial protein synthesis adapts to influx of nuclear-encoded protein. Cell 167: 471-483.
Rubinstein JL, Walker JE, Henderson R. 2003. Structure of the mitochondrial ATP synthase by electron cryomicroscopy. EMBO I 22: 6182-6192.

Rühle T, Leister D. 2015. Assembly of $\mathrm{F}_{1} \mathrm{~F}_{\mathrm{o}}$-ATP synthases. Biochim Biophys Acta 1847: 849-860.

Ryan MT, Hoogenraad NJ. 2007. Mitochondrial-nuclear communications. Annu Rev Biochem 76: 4.1-4.22.

Samluk L, Chroscicki P, Chacinska A. 2018. Mitochondrial protein import stress and signaling. Curr Opin Physiol 3: 41-48.

Sasarman F, Bruned-Guitton C, Antonicka H, Wai T, Shoubridge EA, LSFC Consortium. 2010. LRPPRC and SLIRP interact in a ribonucleoprotein complex that regulates posttranscriptional gene expression in mitochondria. Mol Biol Cell 21: 13151323.

Schägger H, Pfeiffer K. 2000. Supercomplexes in the respiratory chains of yeast and mammalian mitochondria. EMBO J 19: 1777-1783.

Schendzielorz AB, Schulz C, Lytovshenko O, Clancy A, Guiard B, Ieva R, van der Laan M, Rehling P. 2017. Two distinct membrane potential - dependent steps drive mitochondrial matrix protein translocation. J Cell Biol 216: 83-92.

Schleiff E, Becker T. 2011. Common ground for protein translocation: access control for mitochondria and chloroplasts. Nat Rev Mol Cell Biol 12: 48-59.

Schmidt O, Harbauer AB, Rao S, Eyrich B, Zahedi RP, Stojanovski D, Schönfisch B, Guiard B, Sickmann A, Pfanner N, et al. 2011. Regulation of mitochondrial protein import by cytosolic kinases. Cell 144: 227-239.

Shoubridge EA. 2001. Nuclear defects in respiratory chain disorders. Semin Neurol 21: 261-267.

Shpilka T, Haynes CM. 2018. The mitochondrial UPR: mechanisms, physiological functions and implications in aging. Nat Rev Mol Cell Biol 19: 109-120.

Sickmann A, Reinders J, Wagner Y, Joppich C, Zahedi RP, Meyer HE, Schönfisch B, Perschill I, Chacinska A, Guiard B, et al. 2003. The proteome of Saccharomyces cerevisae mitochondria. Proc NatI Acad Sci 100: 13207-13212.

Siira SJ, Spähr H, Shearwood AJ, Ruzzenente B, Larsson NG, Rackham O, Filipovska A. 2017. LRPPRC-mediated folding of the mitochondrial transcriptome. Nat Commun 8: 1532.

Small WC, McAlister-Henn L. 1998. Identification of a cytosolically directed NADH dehydrogenase in mitochondria of Saccharomyces cerevisiae. J Bacteriol 180: 4051-4055.

Smeitink JA, Zeviani M, Turnbull DM, Jacobs HT. 2006. Mitochondrial medicine: a metabolic perspective on the pathology of oxidative phosphorylation. Cell Metab 3: 9-13.

Smith PM, Fox JL, Winge DR. 2012. Biogenesis of the cytochrome bc1 complex and role of assembly factors. Biochim Biophys Acta 1817: 276-286.

Song J, Pfanner N, Becker T. 2018. Assembling the mitochondrial ATP synthase. Proc Natl Acad Sci 20: 2850-2852.

Soto IC, Fontanesi F, Myers RS, Hamel O, Barrientos A. 2012. A heme-sensing mechanism in the translational regulation of mitochondrial cytochrome $c$ oxidase biogenesis. Cell Metab 16: $801-813$.

Sripada L, Tomar D, Prajapati P, Singh R, Singh AK, Sing R. 2012. Systematic analysis of small RNAs associated with human mitochondria by deep sequencing: detailed analysis of mitochondrial associated miRNA. PLoS One 7: e44873.

Stock D, Leslie AGW, Walker JE. 1999. Molecular architecture of the rotary motor in ATP synthase. Science 286: 1700-1705.

Stoldt S, Wenzel D, Kehrein K, Riedel D, Ott M, Jakobs S. 2018. Spatial orchestration of mitochondrial translation and OXPHOS complex assembly. Nat Cell Biol 20: 528-534. 
Szyrach G, Ott M, Bonnefoy N, Neupert W, Herrmann JM. 2003. Ribosome binding of the Oxal complex facilitates co-translational protein insertion in mitochondria. $E M B O / 22: 6448-$ 6457.

Tian Y, Garcia G, Bian Q, Steffen KK, Joe L, Wolff S, Meyer BJ, Dillin A. 2016. Mitochondrial stress induces chromatin reorganization to promote longevity and UPR ${ }^{\mathrm{mt}}$. Cell 165: 1197-1208.

Timón-Gómez A, Nývltova E, Abriata LA, Hosler J, Barrientos A. 2018. Mitochondrial cytochrome $c$ oxidase biogenesis. Recent developments. Semin Cell Dev Biol 76: 163-178.

Topf U, Suppanz I, Samluk L, Wrobel L, Böser A, Sakowska P, Knapp B, Pietrzyk MK, Chacinska A, Warscheid B. 2018. Quantitative proteomics identifies redox switches for global translation modulation by mitochondrially produced reactive oxygen species. Nat Commun 9: 324.

Tsukihara T, Aoyama H, Yamashita E, Tomizaki T, Yamaguchi H, Shinzawa-Itoh K, Nakashima R, Yaono R, Yoshikawa S. 1996. The whole structure of the 13-subunit oxidized cytochrome $c$ oxidase at $2.8 \AA$. Science 272: 1136-1144.

van der Laan M, Wiedemann N, Mick DU, Guiard B, Rehling P, Pfanner N. 2006. A role for Tim21 in membrane potential-dependent preprotein sorting in mitochondria. Curr Biol 16: 2271-2276.

Vogel F, Bornhövd C, Neupert W, Reichert AS. 2006. Dynamic subcompartimentalization of the mitochondrial inner membrane. J Cell Biol 175: 237-247.

Vögtle FN, Wortelkamp S, Zahedi RP, Becker D, Leidhold C, Gevaert K, Kellermann J, Voos W, Sickmann A, Pfanner N, et al. 2009. Global analysis of the mitochondrial N-proteome identifies a processing peptidase critical for protein stability. Cell 139: 428-439.

Wang X, Chen XJ. 2015. A cytosolic network suppressing mitochondria-mediated proteostatic stress and cell death. Nature 524: 481-484.

Weidberg H, Amon A. 2018. MitoCPR-a surveillance pathway that protects mitochondria in response to protein import stress. Science 360: eaan4146.
Weir NR, Kamber RA, Martenson JS, Denic V. 2017. The AAA protein Msp1 mediates clearance of excess tail-anchored proteins from the peroxisomal membrane. Elife 6: e28507.

Weraarpachai W, Antonicka H, Sasarman F, Seeger J, Schrank B, Kolesar JE, Lochmüller H, Chevrette M, Kaufman BA, Horvath R, et al. 2009. Mutation in TACO1, encoding a translational activator of COX I, results in cytochrome $c$ oxidase deficiency and late-onset Leigh syndrome. Nat Genet 41: 833-837.

Wiedemann N, Pfanner N. 2017. Mitochondrial machineries for protein import and assembly. Annu Rev Biochem 86: 685-714.

Wiedemann N, van der Laan M, Hutu DP, Rehling P, Pfanner N. 2007. Sorting switch of mitochondrial presequence translocase involves coupling of motor module to respiratory chain. J Cell Biol 179: 1115-1122.

Wrobel L, Topf U, Bragoszewski P, Wiese S, Sztolsztener ME, Oeljeklaus S, Varabyova M, Lirski M, Chroscicki P, Mroszek S, et al. 2015. Mistargeted mitochondrial proteins activate a proteostatic response in the cytosol. Nature 524: 485-488.

Xia D, Yu CA, Kim H, Xia JZ, Kachurin AM, Zhang L, Yu L, Deisenhofer J. 1997. Crystal structure of the cytochrome $b c_{1}$ complex from bovine heart mitochondria. Science 277: 60-66.

Young JC, Hoogenraad NJ, Hartl FU. 2003. Molecular chaperones Hsp90 and Hsp70 deliver preproteins to the mitochondrial import receptor Tom70. Cell 112: 41-50.

Zara V, Conte L, Trumpower BL. 2007. Identification and characterization of cytochrome $b c_{1}$ subcomplexes in mitochondria from yeast with single and double deletions of genes encoding cytochrome $b c_{1}$ subunits. FEBS J 274: 4526-4539.

Zhang X, Zua X, Yang B, Li Z, Xue Y, Zhou Y, Huang J, Zhao X, Zhou J, Yan Y, et al. 2014. MicroRNA directly enhances mitochondrial translation during muscle differentiation. Cell 158: 607-619.

Zimorski V, Ku C, Martin WF, Gould SB. 2014. Endosymbiotic theory for organelle origins. Curr Opin Microbiol 22: 38-48. 


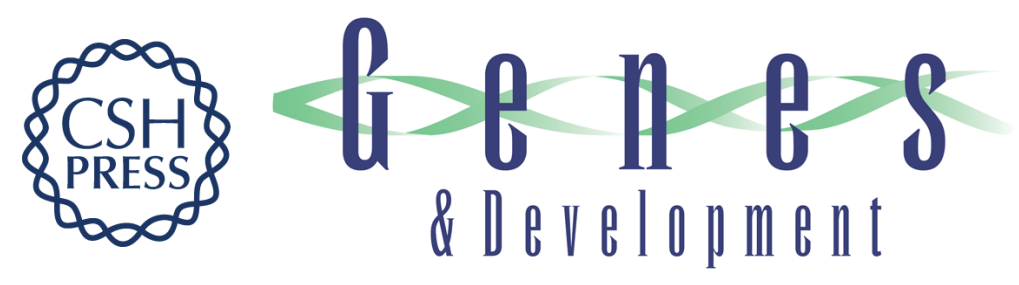

\section{Pathways to balance mitochondrial translation and protein import}

Chantal Priesnitz and Thomas Becker

Genes Dev. 2018, 32:

Access the most recent version at doi:10.1101/gad.316547.118

References This article cites 125 articles, 55 of which can be accessed free at: http://genesdev.cshlp.org/content/32/19-20/1285.full.html\#ref-list-1

Creative This article is distributed exclusively by Cold Spring Harbor Laboratory Press for the first Commons six months after the full-issue publication date (see License http://genesdev.cshlp.org/site/misc/terms.xhtml). After six months, it is available under a Creative Commons License (Attribution-NonCommercial 4.0 International), as described at http://creativecommons.org/licenses/by-nc/4.0/.

Email Alerting Receive free email alerts when new articles cite this article - sign up in the box at the top Service right corner of the article or click here.

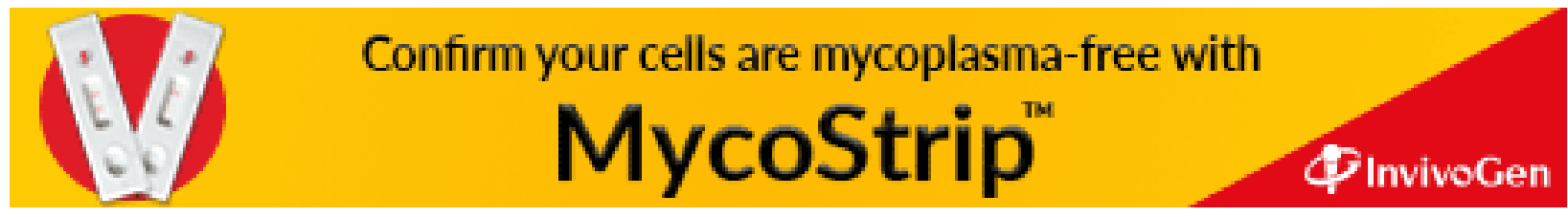

